\title{
The Framework for Effective Human Resource Management at Construction Site
}

\author{
Idris Othman ${ }^{1, *}$, Zain Hashim ${ }^{1}$, Hisham Mohamad ${ }^{1}$, and Madzlan Napiah ${ }^{1}$ \\ ${ }^{1}$ Universiti Teknologi PETRONAS, Civil and Environmental Engineering Department, 32610 Seri \\ Iskandar, Perak, Malaysia
}

\begin{abstract}
Human resource management framework being one of the issue across global construction industries. It is a major concern in the construction industry because inefficiency, delay and cost from construction work could be affected and causing great losses to individuals and organizations. Therefore, resource management framework is changing the way resource management can be approached. Most of the construction companies around the world are implementing human resource management systems to reduce cost, eliminate delaying project, and to provide an efficient framework in their construction site. The objective of this paper is to investigate the effectiveness of implementing human resource management framework in construction site. The methodology included is a combination of literature review, market studies and detailed questionnaire survey before starting the actual survey, a pilot study for this questionnaire was done, which confirms its acceptance. Based on findings from the researcher, most of the company and contractor firms have awareness about management of resource at construction site as human resource management is a major concern on construction industries.
\end{abstract}

\section{Introduction}

Resource management framework is changing the way resource management can be approached. Most of the construction companies around the world are implementing human resource management systems to reduce cost, eliminate delaying project, and to provide an efficient framework in their construction site [Armstrong, M., \& Taylor, S. (2014)]

The study is proposed to develop a solid ground theory in managing and planning the used of resource to the optimum. The current framework will be studied for the best measure that could be taken in managing resource. The top factor is human resource management factor that would be discussed.

\footnotetext{
*Corresponding author: idris_othman@utp.edu.my
} 


\section{Background}

Human resource management in the other hand tend to affect the progress alongside other factors by the skills, motivation and productivity. Human resource plays important part to support estimated progress to be on schedule. In today's business environment, two factors have become common: change and complexity. The nature of business has incorporated these factors into our everyday lives. We work in an environment of constant change and increasing complexity, and must be competitive, productive, customer-focused, and profitable [Huselid, M. A. (2010)].

\subsection{Term of management in human resource management}

Due to this development, the management of human resource highly impact the flow of construction project. However, the main problems are which before the construction project itself started which is by constructing an effective framework. The constraint that cause problem due to inefficiency in managing framework of human resource would be in term of,

1. The sustainability of resource in construction project

2. The delay in project because of inefficient framework

3. Deficiency in current framework that will reduce effectiveness of human resource Management [Su, X., Pan, J., \& Grinter, M. (2015)].

\section{Methodology}

\subsection{Data Evaluation}

The research will be both on qualitative and quantitative. The qualitative are done by interviewing project manager based on many aspects related to resource planning. While the quantitative method are relied on questionnaire with certain aspects to be followed, later both data are combined to acquire most crucial point in determining optimum planning and management of resources in require time frame. By qualitative, the research gained information from project management team mainly from interview. The data are extracted from the interview and transferred into word form. The important part from each of resource management will be extracted for further development.

By quantitative, the research gained numerical data from project team which will consist of critical subject and the review on suggestions for optimizing work frame. Resource management and planning are being implemented successfully at construction industries but some of precautions cause failures or delay in a project frame. 


\section{The Harvard framework}

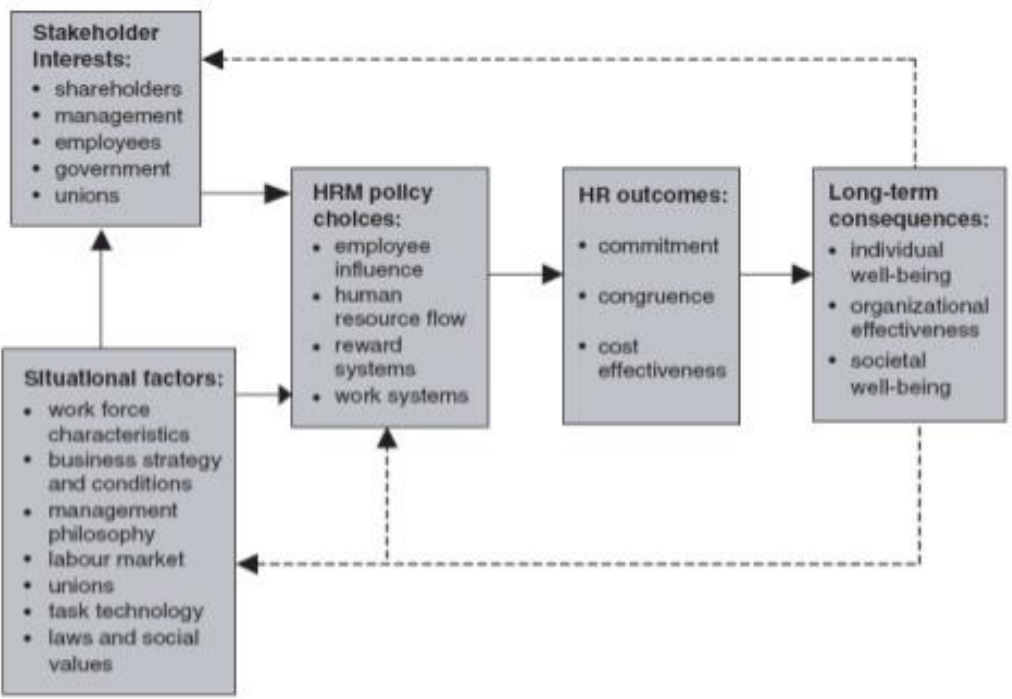

Fig. 1. Example factors in framework

The data used for this study is classified into main and sub data. Though the main data is acquired by questionnaires and online survey, sub data is collected from resources such as journals from websites and books, previous paperwork and thesis done by those who did resource management research in construction industry.

Table 1. List of used Statistical tool

\begin{tabular}{|l|}
\hline \multicolumn{1}{|c|}{ Property } \\
\hline Percentage method, average index (RII) \\
\hline Spearman's Ranking coefficient (correlation test) \\
\hline Cronbach alpha Consistency coefficient (reliability) \\
\hline Validity coefficient (validity test) \\
\hline
\end{tabular}

The information will be dissect in the way of rate (\%) and normal list type of investigation. Some connection test, legitimacy test and Cronbach alpha (unwavering quality) test will be direct to guarantee the creator's believability when figuring and closing the information. The survey in order to gather data on type of feedback given are done during January and February for interview session on 2017. Total of questionnaire distributed are 45 to mainly on-site management personnel which is the project manager, project engineer and also project team member. From total of distributed form, only 35 are received back and only 30 forms are completely answered. 


\section{Result and Discussion}

The data that were collected in questionnaire form as well as interview approach will be further analyze and discussed in this chapter. The chapter will be stressing on the major section of the topic.

The major problem that can be identified from the study are such;

1. Why human resource management framework cause ineffectiveness in construction project?

2. What is the main factor contributing effectiveness of human resource management framework decisions at construction site?

3. What are the points of view of the engineers regarding the factor contributing effectiveness of human resource management framework at construction site and the concerns of dealing with it in construction project?

\subsection{Respondent's Description}

The survey in order to gather data on type of feedback given are done during January and February for interview session on 2017. Total of questionnaire distributed are 45 to mainly on-site management personnel which is the project manager, project engineer and also project team member. From total of distributed form, only 35 are received back and only 30 forms are completely answered.

As minimum requirement for the survey to be considered as valid, the author managed to obtain 30 decent feedback from the respondent. The survey was done with cooperation of respondent to spend time and also give the feedback as soon. The respondent detail is taken, however will be treated with high confidential as stated in the term and condition of the survey form.

The respondents are categorized in 3 group which consist of project manager, project engineer and project team member. These 3 category of respondent feedbacks are used as the main data for the statistical analysis. The data will be first analyses by using SPSS software as well as in Microsoft Excel form for the reliability of the data taken.

Research question 1 will be categorize in sequence from 1(No); 3 (Somewhat) and 5 (Yes). As for Research question 2 will be using from 1(Not Expected and Not Realized); 3 (Expected but Not Realized, Not Expected but Realized); 5 (Expected and Realized). As for Qualitative data from interview, the data provided is only to show on what type of response towards the decision-making process by the personnel point of view and understanding.

\subsection{Respond Towards the Purpose of This Project}

\subsubsection{Research Question 1: Factors Affecting human resource management problem in Construction Site.}

In research question 1, respondents were asked to give their opinion in term of Yes, Somewhat, or No answer. Provided in the table 4 below, the analysis of total respondent was done in percentage $(\%)$ and number. 
Table 2: Factors of Flaw in Human Resource Management at Construction Site.

\begin{tabular}{|c|l|c|c|c|c|c|c|}
\hline No & Item & \multicolumn{2}{|c|}{ Yes } & \multicolumn{2}{|c|}{ Somewhat } & \multicolumn{2}{c|}{ No } \\
\hline 1 & Poor design or planning decisions. & 14 & $46.67 \%$ & 9 & $30.00 \%$ & 7 & $23.33 \%$ \\
\hline 2 & Use of fresh unskilled workers & 15 & $50 \%$ & 8 & $26.67 \%$ & 7 & $23.33 \%$ \\
\hline 3 & Weak enforcement of legislation. & 12 & $40 \%$ & 11 & $36.67 \%$ & 7 & $23.33 \%$ \\
\hline 4 & Site personnel and workers behavior. & 19 & 63.33 & 6 & $20 \%$ & 5 & $16.67 \%$ \\
\hline 5 & Miscommunication between workers. & 25 & $83.33 \%$ & 4 & $13.33 \%$ & 1 & $3.33 \%$ \\
\hline 6 & Poor site supervision. & 18 & $60 \%$ & 10 & $33.33 \%$ & 2 & $6.67 \%$ \\
\hline 7 & Poor site training for the workers. & 20 & $66.67 \%$ & 6 & $20 \%$ & 4 & $13.33 \%$ \\
\hline 8 & $\begin{array}{l}\text { Lack of knowledge regarding the } \\
\text { procedures of activities. }\end{array}$ & 13 & $43.33 \%$ & 12 & $40 \%$ & 5 & $16.67 \%$ \\
\hline 9 & $\begin{array}{l}\text { Lack of preparation regarding the } \\
\text { procedures of activities }\end{array}$ & 15 & $50 \%$ & 6 & $20 \%$ & 9 & $30 \%$ \\
\hline 10 & Neglecting procedures Given & 20 & $66.67 \%$ & 6 & $20 \%$ & 4 & $13.33 \%$ \\
\hline 11 & $\begin{array}{l}\text { Overtime working hours always needed } \\
\text { thus reducing productivity }\end{array}$ & 22 & $73 \%$ & 5 & $5 \%$ & 3 & $10 \%$ \\
\hline
\end{tabular}

By contrast, from three types of answer given, the total respond that toward "yes" are $58.48 \%$ and $16.36 \%$ at "No" which give an overview of the data are consistent. While $25 \%$ from total answer were not sure if the problems are occurring. Nevertheless, the data will be tested for the accuracy on further discussion.

From the data, the highest response of yes is at question 5 which is "Miscommunication between workers", $83.33 \%$ followed by question number 11, "Overtime working hours always needed" at $73 \%$. The overtime working hours factor is to be considered as human cant withstand continuous energy used that will lead to lower productivity on each day. This factor can be further research.

Highest uncertainty answer which are "Somewhat" are given by question number 8 , "Lack of knowledge regarding the procedures of activities" at $40 \%$, this feedback shows that the project members are considered to have knowledge on the procedure in term of framework. The question that have uncertainty are again used as qualitative question to gain further detail on that matter.

The average index for the factor affecting the effective framework for human resource management for the research question type 1 are given by data below. Based on the average index, miscommunication between workers are at highest AI. Thus, it can be assumed as that personal weakness factor are the main attributes for human resource management framework weakness. The statement was also backed by factor of overtime working hours needed that will cause unproductive workers. 
Table 3: Average Index for Factor Affecting the Flaws.

\begin{tabular}{|c|l|c|}
\hline No & \multicolumn{1}{|c|}{ Factors affecting Accident } & Average Index \\
\hline 1 & Miscommunication between workers. & 4.60 \\
\hline 2 & $\begin{array}{l}\text { Overtime working hours cause tiredness and produce } \\
\text { unproductive workers. }\end{array}$ & 4.27 \\
\hline 3 & Poor site supervision. & 4.07 \\
\hline 4 & Poor site training for the workers. & 4.07 \\
\hline 5 & Neglecting procedures Given & 3.07 \\
\hline 6 & Site personnel and workers behavior. & 3.93 \\
\hline 7 & $\begin{array}{l}\text { Lack of knowledge regarding the procedures of } \\
\text { activities. }\end{array}$ & 3.53 \\
\hline 8 & Use of fresh unskilled workers & 3.47 \\
\hline 9 & Poor design or planning decisions. & 3.33 \\
\hline 10 & $\begin{array}{l}\text { Lack of preparation regarding the procedures of } \\
\text { activities }\end{array}$ & \\
\hline 11 & Weak enforcement of legislation. & \\
\hline
\end{tabular}

Based on table above only from question 1, The AI value is falls on range between $(4.50<$ Average Index $<5.00$ ) which means strongly agree from the respondents towards the question. However, from 8 question, the respondents agree towards the question which the value of AI falls in between $(3.50<$ Average Index $<4.50)$, and the rest on neutral side which give the value of AI at $(2.50<$ Average Index < 3.50). Further detail are obtain for the question 10 and 11 by interview session [Abd Majid,et al, 1997]

\section{Conclusion}

Based on the study, among all these factor, Miscommunication between workers, Overtime working hours cause tiredness and produce unproductive workers, Poor site supervision, Poor site training for the workers and neglecting procedure is the top five most factor contribute to the flaw in human resource management at construction site. For conclusion, the framework for Effective Human Resource Management at Construction Site are still arguable with many more potential to be optimized. Thus, more detailed research should be done with more times in conducting the study. 


\section{References}

1. M. Z. Abd. Majid, R. dan McCaffer (1997). Discussion of Work Performance of Maintenance Contractors in Saudi Arabia. Journal of Management in Engineering ASCE, 13, (5) Pg. 91

2. M. Armstrong, S. Taylor, (2014). Armstrong's handbook of human resource management practice: Kogan Page Publishers.

3. M. A. Huselid, (2010). The impact of human resource management practices on turnover, productivity, and corporate financial performance. Academy of management journal, 38(3), 635-672.

4. E. J. Umble, R. R. Haft, M. M. Umble, (2003). Enterprise resource planning: Implementation procedures and critical success factors. European journal of operational research, 146(2), 241-257.

5. X. Su, J. Pan, \& M. Grinter, (2015). Improving Construction Equipment Operation Safety from a Human-centered Perspective. Procedia Engineering, 118, 290-295.

6. X. Wu, Q. Liu, L. Zhang, M. J. Skibniewski, \& Y. Wang, (2015). Prospective safety performance evaluation on construction sites. Accident Analysis \& Prevention, 78, 5872.

7. S. Zhang, J. Teizer, J.-K. Lee, C. M. Eastman, \& M. Venugopal, (2013). Building Information Modeling (BIM) and Safety: Automatic Safety Checking of Construction Models and Schedules. Automation in Construction, 29, 183-195.

8. W. Zhou, J. Whyte, \& Sacks, R. (2012). Construction safety and digital design: A review. Automation in Construction, 22, 102-111.

9. Z. Zhou, Y. M. Goh,\& Li, Q. (2015). Overview and analysis of safety management studies in the construction industry. Safety Science, 72, 337-350.

10. Zaiontz. C., (2014) Real Statistics Using Excel: Cronbach's Alpha [Online]. 